\title{
What Mitigates Economic Growth Volatility in Morocco? \\ : Remittances or FDI
}

Jamal Bouoiyour

CATT, University of Pau, Pau, France

Refk Selmi

ESC, Tunis Business School, Manouba, Tunisia

Amal Miftah

LEDa, University of Paris-Dauphine, Paris, France

\begin{abstract}
The purpose of the paper is twofold. First, it seeks to meticulously analyze the volatility of economic growth and financial flows in the case of Morocco, i.e., remittances and Foreign Direct Investment. Second, it attempts to address the effects of these financial flows on the economic growth volatility. We provide strong evidence that remittances are less volatile than Foreign Direct Investment with respect to the duration, intensity and volatility clustering. Furthermore, remittances can mitigate the volatility of growth, while Foreign Direct Investment flows amplify it. Our results do not imply that financial flows should be privileged by Moroccan authorities. In fact, our results should encourage the government to implement proactive and favourable policies geared towards productive investment.
\end{abstract}

\footnotetext{
* Corresponding Author: Refk Selmi; Campus Universitaire de la Manouba, 2010, Tunisia; Tel: +216 71600615 , Fax:+216 71601311, E-mail: s.refk@yahoo.fr.

Co-authors: Jamal Bouoiyour; Avenue du Doyen Poplawski, 64000 Pau, France; Tel: +33 0559408001, Fax: +33 0559408010, E-mail: jamal.bouoiyour@univ-pau.fr.

Amal Miftah; Place du Maréchal de Lattre de Tassigny, 75775 Paris, France; Tel: +33 01440544 05, Fax: +33 0144054949, E-mail: miftah_amal@yahoo.fr. 
JEL Classifications: F0, F24, G0

Keywords: Economic Growth Volatility, Remittances, FDI, Morocco, Generalized Autoregressive Conditional Heteroskedasticity (GARCH) Models

\section{Introduction}

With the onset of global financial collapse of 2007 and its reliance on dwindling sources of external funding, Morocco, like many developing countries, cannot thrive without migrants' remittances which correspond to represent the international money transfers made by expatriate workers to their home countries. These are the most important source of external financing, much higher than Foreign Direct Investments (FDI). In 2007, for example, remittance flows represented $734 \%$ of development aid, $145 \%$ of FDI and 9\% of Gross Domestic Product (GDP) (Bouoiyour 2013). Despite the severe restrictions on international migration flows, remittances have become critically important to many emigration countries. One of the major 2007 crisis outcomes was the noticeable decrease of worldwide migration. Indeed, the slowdown in economic activity in the host countries resulted in a profound jobs crisis and thus a considerable reduction of migration for work in these countries. However, despite the crisis, remittances from Moroccans living abroad have shown wide resilience. We can expect that these remittances are sent for altruistic reasons ${ }^{1}$, implying that migrants increase the amount transferred to their families during difficult times and thus even in a crisis situation in the host countries, unlike other financial flows like FDI. In actual fact, policymakers perceive remittances as a relatively stable source of foreign exchange and a tool that can relax the household's budget constraints, and thus encourage households in developing countries to invest in the human capital of children. As we consider the case of Morocco, many studies have attempted to highlight their role in improving the welfare of the beneficiary families (Bouoiyour and Miftah 2014), in enhancing the human capital

\footnotetext{
'Remittances seem embedded in a complex reality and mainly driven by distinct socioeconomic interactions among the sender and recipient. There are different motives for remitting: (i) insurance motives in which remittances are served as deeper source of income to insure households against external shocks; (ii) altruism motives, which cover emotional ties to relatives in home countries; and (iii) selfinterest motives, covering essentially investment or entrepreneurial purposes without overlooking personal consumption. At the macro level, remittances are likely to be more stable than other external funding sources, and they also tend to be countercyclical, expanding during economic downturns (Chami et al. 2005). At the micro level, migrants' remittances may play a powerful role on enhancing human welfare (Bouoiyour and Miftah 2015).
} 
levels (Bouoiyour and Miftah 2015, Bouoiyour et al. 2015) and in alleviating poverty (Bouoiyour and Miftah 2014). Similarly, some studies have shown their impact on productivity growth through exchange rate and their counter-cyclicality (Makhouf 2013). However, migration and remittances can also have detrimental effects on the country of origin. Bouoiyour and Miftah (2014) support evidence that remittances exacerbate inequalities. Also, the problem of moral hazard may exist. In other words, remittances decrease the work effort and families who receive them seek employment with less effort. This may lead to a decrease in productivity and ultimately to a drop in economic growth. This question has been largely addressed (Chami et al. 2003), but no study has addressed the issue in the case of Morocco.

Beyond the purely economic effects, international migration and its corollary remittances have substantial social, human and cultural dimensions. Some empirical studies on Moroccan case show the importance of migration in the transmission of values, the acquisition of human capital and the rise of individual aspirations. It is also noteworthy that besides its economic role in his native country, the Moroccan migrant became an agent of social and demographic transformations. He or She contributes to large changes in the consumer habits and the community behavior. The consequent lifestyle and wealth promote wellness aspirations and change widely the parental percep tions of costs and benefits of children and therefore the family choices (Courbage 1996). Ben Seddik (2001) found that in rural area women have pursued an implicit strategy for socio-economic improvement, manifested by controlling their fertility. This means that the migration can have great influence on the inflection of fertility through the content of messages conveyed by the migrant. Thus, migration may play a powerful role of cultural relay and brings the population dynamics which cannot be due solely to socioeconomic changes. We can add that the wives who were left alone are found to invest new responsibilities regarding household management. This yields certain emancipation, another potential source of fertility decline. Arab (2011) argued that circular migration of Moroccans, during short periods can have a significant impact on the lifestyle of female migrants and their relationship with their family and friends. In some cases, migration brings a change in the traditional role of women based solely on reproduction and motherhood. Becoming the main funder of the family and sometimes the head of household, migrant women take a certain influence on their husband. In addition, the status of the child is also modified by the migration. It is the real-life economic integration with respect to households and gender due to the migration and remitiances. The survey conducted in the South of Morocco by Boufraioua (2011) has showed that 
the migration of fathers has a great influence on the process of entering adulthood of children and in their access to highly skilled jobs. The author concluded that the capital owned by of fathers has a direct and intense impact on the life trajectories of their children.

In light of the aforementioned considerations, we invoke the importance of remittances in the macro-economic equilibrium of Morocco, on the one hand, and their relative meaningfulness in explaining national welfare, on the other hand. It is striking to observe the lack of studies that have focused on the impact of financial flows on economic growth volatility. This issue is particularly important for a country like Morocco characterized by its persistent instability of economic growth. It seems therefore crucial for policymakers to rely on a stable and predictable source of external funding. Even FDI and remittance flows are expected to be the more stable components of capital flows, FDI tend in reality to be unstable and highly dependent on the economic situation of their recipient country, while remittances appear to react slightly. The purpose of this paper is to empirically assess this evidence for Moroccan case.

For this purpose, the remainder of the article proceeds as follows. Section II presents a literature survey on the relationship between financial flows and economic growth. Section III depicts the Moroccan international migration and remittance characteristics. Section IV recalls the concept of volatility in order to adequately outline different specifications of conditional volatility. In section $\mathrm{V}$, we apply the optimal Generalized Autoregressive Conditional Heteroskedasticity $(\mathrm{GARCH})$ model to properly and effectively determine the volatility of GDP, remittances and FDI. Then we regress GDP volatility on remittances and FDI. A further step consists on re-estimating the focal relationship, even if potential control variables were accounted for. Section VI discusses our results and offers some economic implications to help policy-makers. Section VII concludes.

\section{Literature Review}

A number of studies have focused on the link between international financial flows and economic growth in developing countries. First of all, we take a close look at the growth effects of FDI. Under certain conditions, FDI is being recognized as an important 
driver of economic development (Borensztein et al. 1998, Keller and Yeaple 2003, Görg and Strobl 2004). Besides bringing capital, it facilitates access to international markets and the transfer of technology coupled with appropriate managerial practices. In addition, it seems that the presence of multinationals can create a competitive pressures as multinationals would compete with local firms, prompting the exit of some domestic firms and forces others to improve their efficiency and productivity. In fact, the effect of Multinational Corporation $(\mathrm{MNC})^{2}$ on productivity of host country firms is ambiguous and depends potentially on certain conditions. Generally speaking, the effect of FDI on growth is not automatic and depends on the characteristics of their recipient country. As asserted by Borensztein et al. (1998), the FDI accelerates economic growth of the host economy, but this requires sufficient absorptive capability of the advanced technologies; for this, host country must have a minimum threshold stock of human capital. Alfaro and Charlton (2007) have analyzed the role of the quality of FDI in economic growth and confirmed that the positive effect of FDI flows on growth is increasing appreciably if one acknowledges the quality of foreign investment based on objective qualitative industry characteristics such as the average skill intensity and the reliance on external capital. Using a panel Vector Autoregression (VAR) model type, Choe (2003) shows that there is a two-way causation between FDI and growth, but the effects are likely to be more apparent from growth to FDI rather than from FDI to growth.

The second issue we address is the short and long term effects of remittances on the macro-economy of recipient countries. There seems to be a strong relationship between migrants' remittances and economic growth, although this linkage is highly heterogeneous among countries. In fact, in the short-run, remittances received by home countries allow them to strengthen their foreign exchange reserves which can serve as effective tool to adjust the macro-economy and therefore affect their macroeconomic equilibrium and GDP growth. From this approach, several studies focusing on the remittances effects on consumption, investment and imports have shown that remittances can influence substantially GDP and marginal propensity to import (El-Sakka and Mcnabb 1999, Glytsos 2002). Using Keynesian type econometric model with a dynamic perspective, and data from five Mediterranean countries, Glytsos (2002) has investigated the effects of remittances on consumption, investment, imports and output and found a rather unstable situation in all countries, with variant positive and negative effects of remittances on growth. The study reveals that the elasticities of induced negative

\footnotetext{
${ }^{2}$ MNC or a Multinational Corporation is an organization that owns production of goods or services in different countries other than their home country.
} 
growth rates of output with respect to falling remittances are much higher compared to the corresponding elasticities regarding rising remittances in the case of Jordan, Egypt and Morocco. On their side, Rao and Hassan (2009) distinguished between the indirect and direct growth effects of remittances by performing the Solow growth model and the Generalized Method of Moments (GMM) panel data estimation method. They found that migrant remittances seem to have positive but minor effects on growth ${ }^{3}$. Other studies showed that remittance receipts may have a negative impact on economic growth through the possible effect of the Dutch disease, which could result from the reduction of the competitiveness of the tradable sector after an appreciation of the real exchange rate. Amuedo-Dorantes and Pozo (2004) have investigated the impact of remittances on the real exchange rate with reference to a panel of 13 Latin American and Caribbean countries. Their analysis indicate that remittances may affect exports through real effective exchange rate or relative prices, showing that remittances have the potential to inflict economic costs on the export sector of receiving countries by minimizing its international competitiveness. Another strand of literature has focused more directly on the relationship between investment and remittances. For instance, Woodruff and Zenteno (2001) found that more than $40 \%$ of the capital invested in microenterprises in urban Mexico is associated with migrants' remittances. Other studies put in evidence that return migration can increase investment in some developing countries like Egypt (McCormick and Wahba 2003) and Tunisia (Mesnard 2004). In particular, they deduce that in countries where access to credit is a major obstacle for entrepreneurship, return migration has raised the propensity of returnees to take up self-employment, and yielded a positive impact of accumulated savings on the decision to become selfemployed. About the relationship between international remittances and financial sector development, Aggarwal (2006) argued that remittance inflows can improve financial sector in developing countries and therefore promote economic growth. Besides stimulating capital accumulation and rapid economic growth, remittances could facilitate the financing of investments in human capital and health as well (Mansuri 2006, ValeroGil 2008).

Finally, we take a close look at the stabilizing role played by remittances and FDI at the macroeconomic level. Given the apparent relationship between remittances and FDI

\footnotetext{
There are seven channels through which remittances may have indirect growth effects: the output growth volatility, the exchange rate which depreciates when it increases, the investment rate, the development of the financial sector which may be crresponded by the ratio of M2 to GDP or the ratio of private sector credits to GDP, the inflation rate, the ratio of foreign direct investment to GDP and the ratio of current government expenditure to GDP.
} 
and economic growth, it is seemingly believable that remittances and FDI can influence macroeconomic fluctuations in recipient countries. As mentioned above, there is not universal agreement about the positive association between remittances or FDI inflows and economic growth. In the case of remittances, Chami et al. (2005) have explained this outcome by the fact that the causes and the effects of remittances remain separate. Many studies, above all at the microeconomic level, showed that migrants' remittances can play an insurance role during times of economic crisis. Migrants transfer because they are concerned about the consumption of their families of origin, and they look to improve the welfare of their families (Lucas and Stark 1985). In addition, according to the New Economics of Labour Migration (NELM), migration is a collective decision making at the household level, which seeks to revenue maximization and especially to economic risks minimization (Taylor and Martin 2001). In other words, migrants can play a major role in mitigating vulnerability to shocks highlighting the counter-cyclical behavior of remittances. Arguably, Ratha (2003) asserted that migrants may increase remittances in times of economic hardship, especially in low-income countries where their families may depend significantly on remittances as a source of income and may live at close to subsistence levels. Moreover, Chami et al. (2005) indicated that remittances have a tendency to move counter-cyclically with the GDP in recipient countries. Ebeck and Combes (2012), by studying the macroeconomic impacts of natural disasters on the output growth volatility, showed that the effect of natural disasters disappears for a remittance ratio above $8 \%$ of GDP, while remittances exacerbate the destabilizing effects of natural disasters when they exceed 17\% of GDP. Besides, Bouhga-Hagbe (2006) putted in evidence that altruism can be captured by a negative long-run correlation between remittances and agricultural GDP, which is used as an indicator of economic hardship in the home country. Other external inflows like official development aid are of great need and could significantly mitigate the vulnerability of low-income countries to economic shocks. In this vein, Guillaumont and Le Goff (2010) presented a comparative analysis of the stabilizing effect of Official Development Assistance (ODA) and migrant remittances. They showed that remittances appear to be stabilizing in more cases than official aid. Neagu and Schiff (2009) compared the cyclically and stabilizing impacts of ODA, FDI and remittances. They suggest that it seems effective to separately examine counter-cyclical and stabilizing effects. They found that ODA is more stable than remittances in $73 \%$ of the investigated countries which in turn are more stable than FDI in $72 \%$ of them. With respect to cyclicality, the results reveal that remittances are pro-cyclical, FDI more pro-cyclical, and ODA counter-cyclical. Finally, ODA has a 
stabilizing impact in $56 \%$ of the studied countries, while remittances and FDI have no effect in most of them.

\section{Remittance in Moroccan Context}

According to the World Bank estimates, in 2011, remittances to developing countries have reached 373 billion US dollars and over 500 billion US dollars worldwide. These flows have risen steadily for many years in developing countries to become as important as direct investment flows and much higher than the amount of official development assistance. The size of remittance flows is much more significant than official estimates that underestimate the real levels of remittance flowing back to the origin countries because they only include those remittances which come back through official means. In the case of Morocco, migrants' remittances have been perceived one of the major sources of foreign currency and play a significant role in national economy, since $10 \%$ of total population of Morocco have migrated internationally. According to World Bank data, Morocco has received 7.2 billion US dollars in 2011, about 7.24\% of its GDP. As a consequence of the current global economic crisis, remittance flows have decreased for all regions of the world. In Morocco, while volumes have declined in 2008 and 2009, it is not possible to observe a phenomenon of collapse. For this country, the stability of remittance flows is an important policy issue that is relevant for the analysis of its external and internal vulnerabilities.

Table 1 provides a summary of the movement in the main elements of the Moroccan balance of payments as a share of GDP. As a percentage of GDP, remittances appear wider than FDI. Together with tourism, migrants' remittances represent the country's major source of foreign currency receipts. 
Table 1. Main elements of the Moroccan balance of payments

\begin{tabular}{|l|c|c|c|c|c|c|}
\hline & $\mathbf{1 9 9 0}$ & $\mathbf{1 9 9 5}$ & $\mathbf{2 0 0 0}$ & $\mathbf{2 0 0 5}$ & $\mathbf{2 0 1 1}$ & $\mathbf{2 0 1 2}$ \\
& $\sim \mathbf{1 9 9 4}$ & $\sim \mathbf{1 9 9 9}$ & $\mathbf{2 0 0 4}$ & $\mathbf{2 0 1 2}$ & $\mathbf{2 0 1}$ & \\
\hline Current account balance & -1.6 & -0.8 & 2.4 & -4.3 & -8.1 & -9.8 \\
\hline Travel credits & 3.9 & 4.2 & 6.5 & 7.8 & 7.4 & 6.9 \\
\hline Spending of investment income & 4.3 & 3.5 & 2.6 & 2.4 & 2.9 & 3 \\
\hline Remittances & 7 & 5.9 & 8.2 & 8.4 & 8 & 7.5 \\
\hline Foreign direct investment & & & 3.4 & 4.2 & 3.2 & 3.5 \\
\hline $\begin{array}{l}\text { Investment and private debt } \\
\text { flows to Morocco }\end{array}$ & 1.5 & 2.5 & 4.1 & 4.8 & 3.8 & 3.7 \\
\hline
\end{tabular}

(Source) Division of financial research and perspective (2013).

At the international level, at over 6.5 billion US dollars in 2012, they placed Morocco as the 15th largest recipient of remittances in developing countries. In 2012, the country continued to depend on these external flows which provided an essential financial support to its balance of payments and had a significant impact in its GDP. With respect to economic growth, the World Bank show that over the period 1980 2010, growth in Morocco averaged about 4\%. Morocco's economy has been performing relatively well with an average growth rate of $5 \%$ over the past few years.

\section{Methodological Framework}

The primary objective of the present article is twofold: Firstly, we attempt to determine the optimal model allowing us to appropriately measure the volatility of Moroccan GDP growth and that of financial flows, i.e., remittances and FDI. Secondly, we rigorously attempt to model the volatility of GDP growth with various relevant explanatory variables including particularly remittances and FDI. Economic theory 
assumes that these variables act oppositely on the volatility of economic growth. Our aim throughout is to address potential impact of these variables on Moroccan economic growth volatility. The conclusions drawn from our results may have important economic implications and may be useful for policymakers' actions.

\section{A. GARCH models}

Economic agents act in an uncertain economic environment where the volatility of commodity prices increases continuously, aggravating the probability of risk' occurrence. Obviously, the risk is closely correlated to instantaneous variability of asset returns or accurately to volatility. It seems therefore necessary to determine an appropriate econometric technique that may properly captures unobservable processes. Thus, we should be cautious in choosing the best volatility measurement.

The conventional models consider that the distribution of asset returns is stable, implying that economic agents formulate their expectations at the same way over time. Practically, this evidence is obviously far from reality, since during periods of great agitation, the variance-covariance of returns may move excessively. As a result, the naïve models or the standard specifications are unable to detect effectively the conditional volatility process and to account for transitory and permanent components, which stem in time series fluctuations and weight between tranquil and turbulent periods. The GARCH-type modeling has been and continuous to be a valuable tool in financial economics after the pioneering study of Engle (1982). Statistically, financial markets data seem distinguished during volatility clustering in which time series show excessive periods of high volatility and periods of low one. In fact, time-variant is more common than constant volatility. In that context, GARCH extensions have been considered as more appropriate to define volatility (Bollerslev et al. 1993). These models are efficient for describing the volatility of the conditional variance by taking into account the characteristics of series using the past errors in estimates.

Because choosing an optimal model among various GARCH specifications seems most convenient, we apply different extensions in order to determine the best model that is able to determine the conditional processes of remittances $(R E M)$, foreign direct investments $(F D I)$ and economic growth $(G D P)$. Since no single measure of volatility has dominated the existing empirical literature, the more parsimonious techniques adequately depicting the volatile behaviors of the focal variables can be selected using 
standard historical evaluation criteria such as the Akaike (AIC), the Bayesian (BIC) and Hannan-Quinn (HQ) information criteria. Regarding the forecasting performance, some loss functions are also been employed including Root Mean Square Error (RMSE), Mean Absolute Error (MAE) and Bias proportion (BP). These criteria are, to our best knowledge, sufficient to judge the quality of estimation. Initially, it is crucial to recall that standard GARCH model developed by Engle (1982) and generalized by Bollerslev (1986) assume that the conditional variance follows an Autoregressive-Moving-Average (ARMA) process. It allows a representation of the autoregressive conditional variance process. It is expressed as follows:

$$
\sigma_{t}^{2}=\omega+\sum_{i=1}^{q} \alpha_{i} \varepsilon_{t-i}^{2}+\sum_{i=1}^{p} \beta_{j} \sigma_{t-j}^{2}
$$

where $\beta_{i}, \beta_{i}, \omega$ are the parameters to estimate.

Subsequently, we have shown a sharp evolution of GARCH extensions (Tong 1990, Nelson 1991, Ding et al. 1993, Zakoin 1994, Bauwens and Storti 2008). These models may be linear or nonlinear, symmetrical or asymmetrical. While such analyses accurately gauge the excessive volatility of financial variables, they do not account for asymmetry which means the leverage effect considering the sign of innovations and not only its amplitude and nonlinearity or switching regime that may stem in investigated time series. Unlike the asymmetrical and nonlinear GARCH models, the symmetrical and linear modeling imposes the same sign of parameters over time. Appendix 1 reports the different GARCH specifications used in our study.

\section{B. Economic growth volatility model}

In the present study, we will focus on the roles of remittances and FDI in explaining the volatility of economic growth. Normally, financial flows are closely linked to the economies where capital intensity is high. Some researches indicate that remittances and FDI are pro-cyclical and volatile (Jackman et al. 2010, Neagu and Schiff 2009). However, other empirical studies suggest that they have controversial influences, by revealing that remittances are stable and countercyclical (Bugamelli and Paterno 2008).

The current research re-explores the empirical connection between financial flows and economic growth volatility, by incorporating control variables such as domestic 
credits to GDP and openness. To this end, we carry out several volatility' specifications and we use both naïve techniques and sophisticated models on the conditional volatility basis to ascertain the robustness of our findings.

The existing literature suggests different factors as main drivers of economic growth instability. This study disentangles the short-run dynamic between GDP volatility, remittances to GDP ratio and FDI to GDP ratio by accounting for other variables supposed to have a great role in explaining the volatility of economic growth. The model to be estimated is written as follows:

$$
y_{t}=a_{0}+a_{1} x_{1 t}+\alpha_{2} x_{2 t}+a_{3} x_{3 t}+a_{4} x_{4 t}+a_{5} x_{5 t}+\alpha_{6} x_{6 t}+\varepsilon_{t}
$$

where $x_{1}$ is the volatility of GDP (in real terms). $x_{1}$ and $x_{3}$ represent the variables of interest, namely, remittances and FDI respectively. The rest of time series are the control variables. So, $x_{3}$ denotes the lagged GDP of one period and $x_{5}$ is the squared lagged GDP. $x_{5}$ is the credits to the economy divided by GDP, $x_{6}$ denotes the openness, i.e., exports and imports to GDP ratio, and $\varepsilon_{t}$ is the error term to be white noise.

\section{Main Findings}

\section{A. Preliminary analysis}

Before measuring the volatility of GDP, remittances and FDI and estimating the relationship between them, we start by a preliminary analysis of these variables using quarterly data over the period 2000 2009 ${ }^{4}$ collected from Econstats ${ }^{\mathrm{TM}}$ and exchange office of Morocco. The descriptive statistics are reported in Table 2. It is clear that the Jarque-Bera test rejects the null hypothesis of a Gaussian distribution of GDP returns and those of FDI, while it accepts it for the case of remittances returns. GDP and FDI returns show a negative asymmetry, i.e., skewness and thus admitting a symmetrical distribution is plausible for the two countries in question, but remittances show a positive asymmetry. Except for remittances, Kurtosis is greater than 3 for all variables under consideration,

${ }^{4}$ The chosen period of study is due to the availability of data. 
indicating that the distribution of each series is flatter than the Gaussian distribution.

Table 2. Preliminary analysis statistics

\begin{tabular}{|l|c|c|c|}
\hline & $\boldsymbol{r}_{\text {GDP }}$ & $\boldsymbol{r}_{\text {REMITTANCES }}$ & $\boldsymbol{r}_{\text {FDI }}$ \\
\hline Mean & $-2.48^{\mathrm{E}}-05$ & -0.006094 & -0.025771 \\
\hline Median & 0.001442 & -0.012378 & 0.017499 \\
\hline Maximum & 0.104484 & 0.371875 & 2.837132 \\
\hline Minimum & -0.118370 & -0.375297 & -3.123113 \\
\hline Standard deviation & 0.042136 & 0.185237 & 0.967503 \\
\hline Skewness & -0.072678 & 0.282753 & -0.235811 \\
\hline Kurtosis & 4.325246 & 2.610268 & 6.034487 \\
\hline Jarque-Bera & 8.740164 & 0.746839 & 14.93169 \\
\hline
\end{tabular}

(Note) $r_{t}=\log \left(S_{t}\right)-\log \left(S_{t-1}\right) . S_{t}$ denotes $G D P$, remittances and $F D I$ returns, respectively.

To be more effective in our investigation, we have tested the autocorrelations and the occurrence of asymmetry on conditional volatility in our three variables of interest. Simple diagnostic can be used to see whether there we should account for asymmetry when analyzing the focal series is the correlation between squared returns and lagged returns, i.e., $\operatorname{corr}\left(r^{2}, r_{t-1}\right)$. A negative value of the correlation coefficient implies the existence of a leverage effect. The results of autocorrelation, $\mathrm{ARCH}$ and leverage effects tests are summarized in Table 3. The findings from Durbin-Watson (DW) test indicate that there is no evidence of autocorrelation in the mean equation of all time series studied. It is also clear that all the variables exhibited strong ARCH effect, implying that the mean equation did not adequately capture volatility for concerned countries, hence it seems not necessary to estimate the GARCH models based on this mean equation. We also clearly note that the correlations between the squared returns and lagged returns have negative values for GDP and remittances and positive for FDI. This highlights the presence of asymmetric effects for the first variables and its absence for the third one. 
Table 3. Leverage effect on conditional volatility

\begin{tabular}{|c|c|c|c|}
\hline & DW test $\left(r_{t-1}\right)$ & ARCH LM test $\left(r_{t-1}\right)$ & $\rho\left(r^{2}, r_{t-1}\right)$ \\
\hline GDP & 1.93 & $\begin{array}{c}27.34^{* * *} \\
{[0.0000]}\end{array}$ & -0.6093 \\
\hline REMITTANCES & 1.87 & $\begin{array}{c}22.18^{* * *} \\
{[0.0000]}\end{array}$ & -0.2115 \\
\hline FDI & 1.89 & $\begin{array}{c}22.69 * * * \\
{[0.0000]}\end{array}$ & 0.3844 \\
\hline
\end{tabular}

(Note) [.] $=p$-value, $p$-value $<0.01=* * *, p$-value $<0.05=* *, p$-value $<0.01=*$.

Now, to choose the best model, we firstly employed standard criteria such as the AIC, the BIC and the HQ. These criteria evaluate the models based on the history of volatility. ${ }^{5}$ Secondly, to have good forecasting performance, we used the forecast error which is calculated as the difference between the observed and the predicted values. In particular, we calculated loss functions based on the RMSE, the MAE and the $\mathrm{BP}^{6}$ to compare the performance of different models for prediction (Koksal 2009). The model with the minimum loss function is assumed to be the optimal one.

\section{A. Results}

\section{GDP}

Whatever the criterion of historical evaluation or the criterion of the loss function, the optimal model is the Threshold-GARCH (T-GARCH) initially proposed by Tong

\footnotetext{
${ }^{5}$ The formula of the different historical evaluation can be written as follows:

Akaike information criterion : $-2 \log$ (vraisemblance $)+2 k$

Bayesian information criterion : $-2 \log ($ vraisemblance $)+\log (N) \cdot k$

Hannan-Quinn information criterion: $-2 \log ($ vraisemblance $)+2 k \cdot \log (\log (N))$

where $k$ the degree of freedom and $N$ is the number of observations.

${ }^{6}$ The formulas of the loss functions are expressed as follows:

Mean Square Error : $M S E=\frac{1}{n} \sum_{i=1}^{n}\left(\sigma_{i}-h_{t}\right)^{2}$

Root Mean Square Error : $R M S E=\left[\frac{1}{n} \sum_{i=1}^{n}\left|\sigma_{i}-h_{t}\right|^{2}\right]^{1 / 2}$

Bias proportion: $B P=\frac{1}{n} \sum_{i=1}^{n}\left|\frac{\sigma_{i}-h_{r}}{\sigma_{i}}\right|$
} 
(1990) and extended by Zakoin (1994) which takes into account both asymmetry and nonlinearity in the process of volatility. It is expressed as follows:

$$
\sigma_{t}^{2}=\omega+\sum_{i=1}^{q}\left(\alpha_{i}\left|\varepsilon_{t-i}\right|+\gamma_{i}\left|\varepsilon_{t_{-} i}^{+}\right|\right)+\sum_{i=1}^{p} \beta_{j} \sigma_{t-j}
$$

where $\alpha_{i}, \beta_{i}, \omega$ and $\gamma$ are the parameters to estimate.

The main results of estimates are reported in Table 4 . The volatility appears persistent and tends towards long memory process since $\alpha+\beta+0,5 \gamma=1.07$ is not for from 1 . The asymmetrical effect is positive and statistically significant implying that the effect of bad news on the conditional variance exceeds that of good news. Indeed, the degree of asymmetry $\left(\frac{\alpha+\gamma}{\alpha}\right)$ which measures the relative influence of bad news on volatility seems strong in our case (it amounts 0.9214). Additionally, the intensity of negative shocks $(-\alpha+\gamma=1.46)$ is greater than that of positive shocks $(\alpha+\gamma=0.8)$. It is also well seen from Figure 1 that the Moroccan GDP tends to stabilize. Precisely, the variance of GDP decreases from one year to another. This result may be due to the fact that the sharp de-correlation between the GDP and the climatic conditions in the last years tends to smooth the volatility of the variance. 
Table 4. Volatility of GDP

\begin{tabular}{|c|c|}
\hline \multicolumn{2}{|c|}{ Dependent variable: $\left(r_{t}=\log \left(G D P_{t}\right)-\log \left(G D P_{t-1}\right)\right.$} \\
\hline \multicolumn{2}{|c|}{ Mean equation } \\
\hline $\mathrm{C}$ & $\begin{array}{l}-0.0028 * \\
(-2.0316)\end{array}$ \\
\hline$r_{t-1}$ & $\begin{array}{c}-0.6325 * * * \\
(-3.7151)\end{array}$ \\
\hline \multicolumn{2}{|c|}{ Variance equation } \\
\hline$\omega$ & $\begin{array}{c}2.05 \mathrm{E}-05 \\
(0.1249)\end{array}$ \\
\hline$\alpha$ & $\begin{array}{l}-0.2924^{*} \\
(-1.8592)\end{array}$ \\
\hline$\beta$ & $\begin{array}{l}0.2944 * \\
(1.8174)\end{array}$ \\
\hline$\gamma$ & $\begin{array}{c}1.1756^{* * * *} \\
(3.7377)\end{array}$ \\
\hline Duration of persistence: $\alpha+\beta+0.5 \gamma$ & 1.0104 \\
\hline $\mathrm{ARCH}$ and GARCH effects: $\alpha+\beta$ & 0.0020 \\
\hline Leverage effect: $\gamma$ & 1.1756 \\
\hline Intensity of negative shock: $-\alpha+\gamma$ & 1.4680 \\
\hline Intensity of positive shock: $\alpha+\gamma$ & 0.8832 \\
\hline
\end{tabular}

(Notes) (i) $\omega$ : the reaction of conditional variance; $\alpha$ : the ARCH effect; $\beta$ : the GARCH effect; $\gamma$ : the leverage effect.

(ii) $* * *$, and $* * *$ indicate that the variable is statistically significant at $10 \%, 5 \%$, and $1 \%$, respectively. 
Figure 1. Volatility of GDP

GDP / T-GARCH
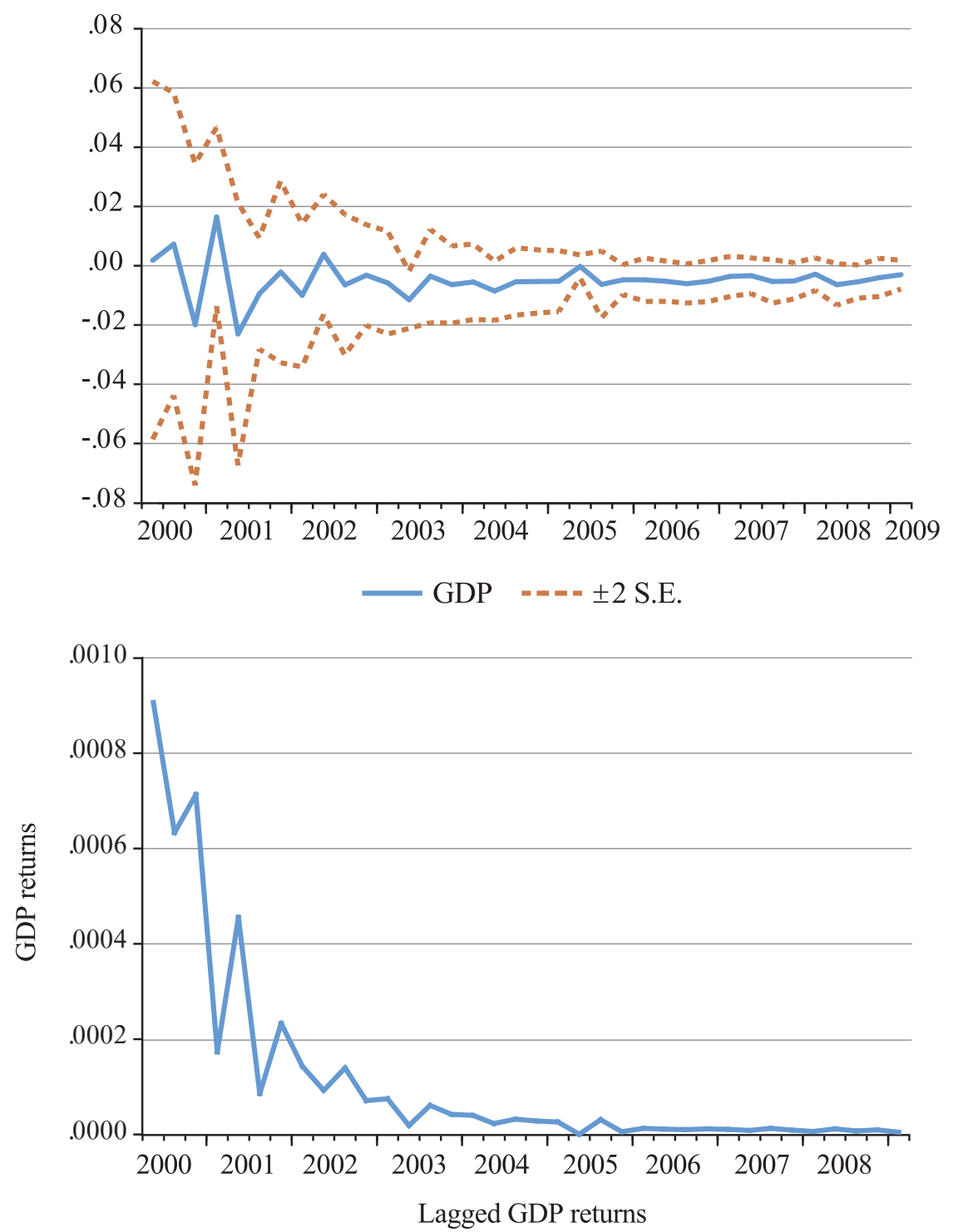

Conditional variance 


\section{Financial flows}

\section{1) Remittances}

The best model chosen by considering the results from both information criteria and loss functions for remittances is the CMT-GARCH model recently used by Bouoiyour and Selmi (2014) that account for multiple threshold orders, weight between high and low volatility, leverage effect and that decomposes the process of volatility into a longrun time varying trend and short-run deviations from trend (Appendix 2). This model is written as follows:

$$
\sigma_{t}^{2}=\omega+\alpha \varepsilon_{t-1}^{2}+\beta\left(\omega+\left(\alpha+\gamma I_{\left(\varepsilon_{t-2 \succ 0}\right)}\right) \varepsilon_{t-2}^{2}+\beta \sigma_{t-2}^{2}\right)
$$

where $\alpha_{i}, \beta_{i}$ and $\omega$ and $\gamma$ are the parameters to estimate.

Table 5 provides more details about the estimated parameters. From Equation (1) we show that the leverage effect is insignificant for $R E M$, indicating that neither the bad nor the good news have any impact on the conditional volatility. In addition, the intensity of both negative and positive shocks is seemingly low for REM because they amount respectively $-\alpha+\gamma=-0.02$ and $\alpha+\gamma=0.20$. The persistence of conditional volatility $(\alpha+\beta+0.5 \gamma)$ amounts 0.27 . It appears also low since the duration of persistence is far from 1. A common characteristic of financial time series returns is the volatility clustering that may be defined as the succession of periods when returns change slightly and others where changes in returns are larger. For our cases of study and particularly for $R E M$, we note that the sum of $\alpha$ and $\beta$ is lower, implying the absence of volatility clustering.

\section{2) FDI}

Using several information criteria and loss functions, we show that for FDI the optimal model is the T-GARCH, which accounts for nonlinearity and asymmetry in the conditional variance process. The formula of this specification is already mentioned above in section V. Equation (2) in Table 5 reports the estimated parameters. We clearly show that the leverage effect is positive and significant for $F D I$, indicating that bad news have more influence on the volatility process than good news. In addition, the intensity of negative shock seems stronger for $F D I$, exceeding $1(-\alpha+\gamma=1.21)$. The duration of persistence $(\alpha+\beta+0.5 \gamma)$ appears also important, amounting 1.23. This means that 
FDI tends to follow a long memory process or explosive process since the duration of persistence sharply exceeds 1 . Besides, the sum of ARCH and GARCH effects is higher for FDI, supporting the occurrence of volatility clustering.

In sum, we found that it is crucial when assessing the instability of REM and FDI to account for asymmetry and nonlinearity. The duration of persistence and the ARCH and GARCH effects appear stronger for FDI. Thus, we can deduce that considering the conditional volatility characteristics, remittances behave better than FDI, Figure 2 confirms the more volatile and persistent behavior of FDI, i.e., the volatility of FDI takes more time to smooth than that of remittances. 
Table 5. Volatility of financial flows

\begin{tabular}{|c|c|c|}
\hline \multicolumn{3}{|c|}{ Dependent variable: $\left(r_{t}=\log \left(G D P_{t}\right)-\log \left(G D P_{t-1}\right)\right.$} \\
\hline & (1) & (2) \\
\hline & $R E M$ & $F D I$ \\
\hline \multicolumn{3}{|c|}{ Mean equation } \\
\hline $\mathrm{C}$ & $\begin{array}{c}-0.0416 \\
(-0.2795)\end{array}$ & $\begin{array}{c}-0.0468 * * * \\
(-3.6597)\end{array}$ \\
\hline$r_{t-1}$ & $\begin{array}{c}-0.4534 * * * \\
(-6.6107)\end{array}$ & $\begin{array}{c}-0.3037 * * \\
(-2.3446)\end{array}$ \\
\hline \multicolumn{3}{|c|}{ Variance equation } \\
\hline$\omega$ & $\begin{array}{c}0.5929 * * \\
(2.7142)\end{array}$ & $\begin{array}{c}0.0048 \\
(1.4836)\end{array}$ \\
\hline$\alpha$ & $\begin{array}{c}0.1145 \\
(0.0086)\end{array}$ & $\begin{array}{c}-0.2597 \\
(-1.4628)\end{array}$ \\
\hline$\beta$ & $\begin{array}{c}0.1128 * * \\
(2.3706)\end{array}$ & $\begin{array}{c}1.0122 * * * \\
(8.1525)\end{array}$ \\
\hline$\gamma$ & $\begin{array}{c}0.0944 \\
(1.0826)\end{array}$ & $\begin{array}{l}0.9593 * \\
(1.7784)\end{array}$ \\
\hline Duration of persistence: $\alpha+\beta+0.5 \gamma$ & 0.2745 & 1.2325 \\
\hline ARCH and GARCH effects: $\alpha+\beta$ & 0.2253 & 0.7525 \\
\hline Leverage effect: $\gamma$ & 0.0944 & 0.9593 \\
\hline Intensity of negative shock: $-\alpha+\gamma$ & -0.0201 & 1.2190 \\
\hline Intensity of positive shock: $\alpha+\gamma$ & 0.2089 & 0.6996 \\
\hline
\end{tabular}

(Notes) (i) $\omega$ : the reaction of conditional variance; $\alpha$ : the ARCH effect; $\beta$ : the GARCH effect; $\gamma$ : the leverage effect.

(ii) ***, and $* * *$ indicate that the variable is statistically significant at $10 \%, 5 \%$, and $1 \%$, respectively. 
Figure 2. Volatility of financial flows

GDP / T-GARCH
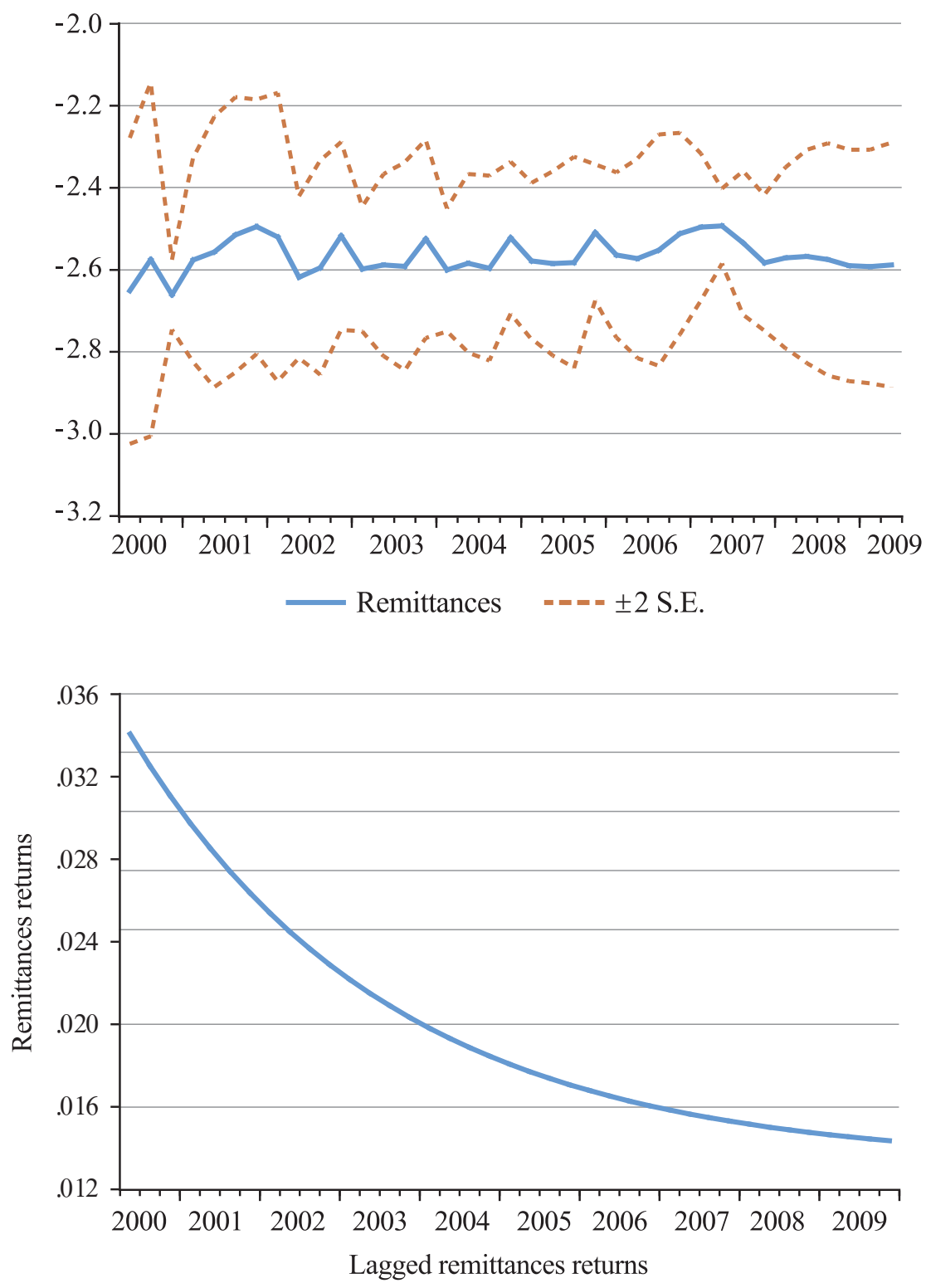

Conditional variance 


\section{FDI / T-GARCH}

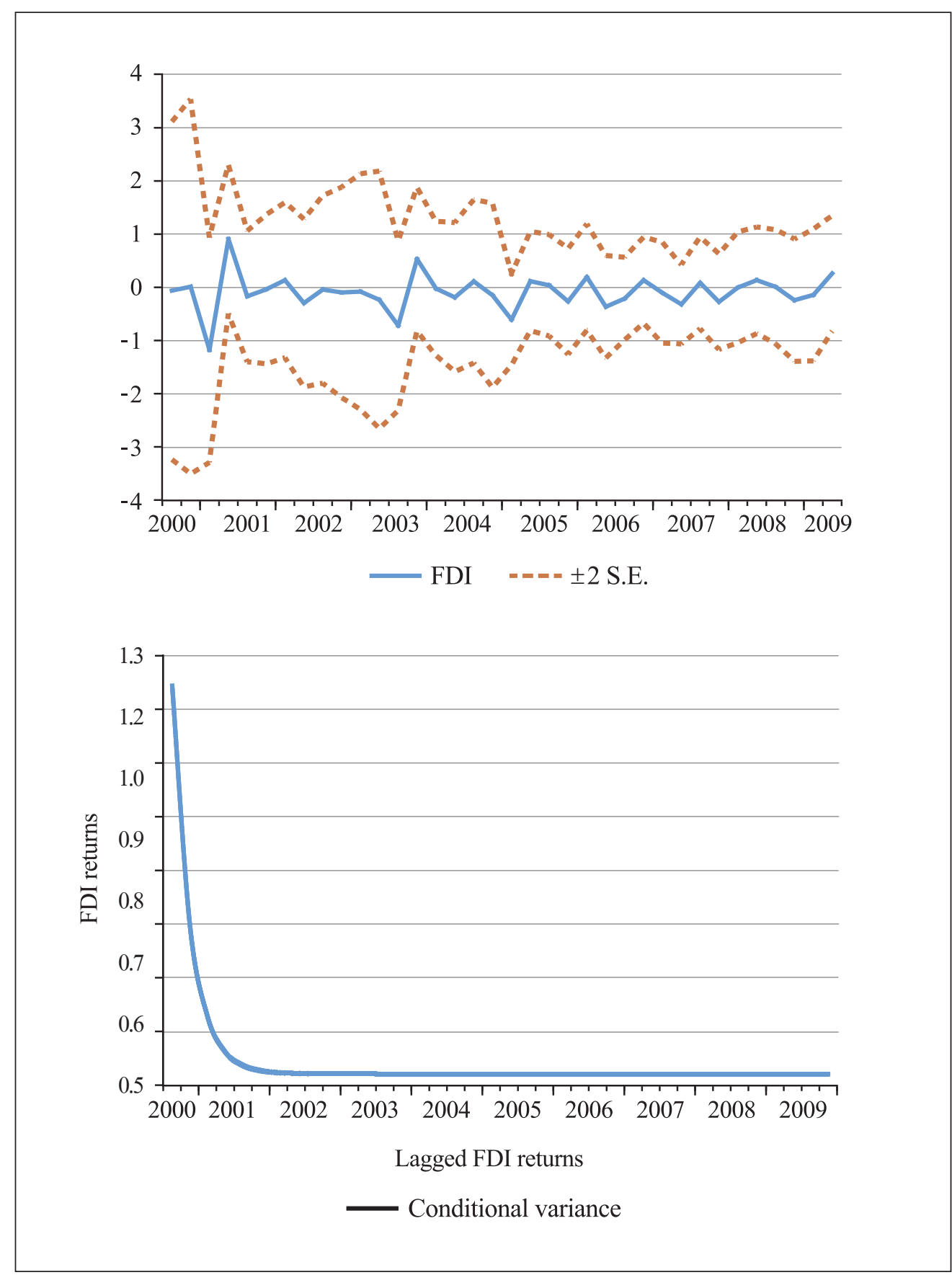


After determining the volatility of GDP and comparing the instability of $R E M$ to that of $F D I$, it is time to address whether financial flows raise or reduce economic growth volatility. To do so, we use the optimal GARCH model that links the returns of GDP with financial flows and while incorporating additional explanatory variables which are shown in Equation (2) in Table 6. The first best model specification chosen among various GARCH extensions (Appendix 3) seems asymmetrical (AP-GARCH), while the second one considers both the switching regime and the leverage effect (CMT-GARCH). The AP-GARCH model is expressed as follows:

$$
\sigma_{t}^{\varphi}=\omega+\sum_{i=1}^{q} \alpha_{i}\left(\left|\varepsilon_{t-i}\right|+\gamma_{i} \varepsilon_{t-i}\right)^{\varphi}+\sum_{i=1}^{p} \beta_{j} \sigma_{t-j}^{\varphi}
$$

where $\alpha_{i}, \beta_{i}, \omega$ and $\gamma$ are the parameters to estimate.

The results are summarized in Table 6 . We notice that remittances play a stabilizing role. Indeed, the remittances (REM) have a negative and significant effect on the dependent variable and then reduce the volatility of growth in Morocco. It is also well shown that FDI have a positive impact on the volatility of Moroccan economic growth. In other words, the foreign direct investments accentuate the GDP instability, inversely to remittances. Nevertheless, this outcome clearly indicates the opposite behavior of the two financial flows, confirming therefore the previous assessment of conditional volatility of remittances and FDI.

It is also revealed from our results that openness has a positive and significant impact on the volatility of Moroccan GDP, but this effect seems minor. More precisely, an increase by $10 \%$ in openness leads to an increase in the instability of GDP by $0.41 \%$. This means that openness, as practiced in Morocco, may serve as an element that accentuates the volatility of economic growth. It is known that Morocco is specialized in exporting products mainly characterized by low technological and innovative contents. Likewise, imports are concentrated in raw materials belonging high uncertainty and great speculation. This result is inconsistent with Bouoiyour (2008)'s study, showing that openness can affect negatively Moroccan growth. As for the variable relative to Credits, it reduces certainly the economic growth volatility. 
Table 6. The link between economic growth volatility and financial flows

\begin{tabular}{|c|c|c|}
\hline \multicolumn{3}{|c|}{ Dependent variable: $\left(r_{t}=\log \left(G D P_{t}\right)-\log \left(G D P_{t-1}\right)\right.$} \\
\hline & (1) & (2) \\
\hline & AP-GARCH & CMT-GARCH \\
\hline \multicolumn{3}{|c|}{ Mean equation } \\
\hline$C$ & $\begin{array}{l}0.0729 \\
(1.0676)\end{array}$ & $\begin{array}{c}92.372 * * * \\
(18.6354)\end{array}$ \\
\hline$R E M / G D P$ & $\begin{array}{l}-0.0352^{*} \\
(-1.7215)\end{array}$ & $\begin{array}{l}-0.0293 * \\
(-1.8840)\end{array}$ \\
\hline$F D I / G D P$ & $\begin{array}{c}0.00676^{*} \\
(1.6784)\end{array}$ & $\begin{array}{l}0.0252^{*} \\
(1.7459)\end{array}$ \\
\hline$G D P(t-1)$ & - & $\begin{array}{c}-15.244 * * * \\
(-10.2840)\end{array}$ \\
\hline$G D P(t-1)^{2}$ & - & $\begin{array}{c}0.6632 * * * \\
(17.5896)\end{array}$ \\
\hline Credits & - & $\begin{array}{c}-0.4082^{* * *} \\
(-6.5070)\end{array}$ \\
\hline Openness & - & $\begin{array}{l}0.0416^{*} \\
(1.7544)\end{array}$ \\
\hline \multicolumn{3}{|c|}{ Variance equation } \\
\hline$\omega$ & $\begin{array}{l}3.00 \mathrm{E}-05 \\
(0.9984)\end{array}$ & $\begin{array}{l}0.0001 * * \\
(2.7791)\end{array}$ \\
\hline$\alpha$ & $\begin{array}{c}-0.0683 \\
(-0.9227)\end{array}$ & $\begin{array}{l}0.7191^{*} \\
(1.1460)\end{array}$ \\
\hline$\beta$ & $\begin{array}{c}0.9925 \\
(0.3588)\end{array}$ & $\begin{array}{c}0.2114 \\
(0.3239)\end{array}$ \\
\hline$\gamma$ & $\begin{array}{c}1.0580 * * * \\
(4.2153)\end{array}$ & $\begin{array}{c}-0.0224 \\
(-0.0088)\end{array}$ \\
\hline
\end{tabular}

(Notes) (i) $\omega$ : the reaction of conditional variance; $\alpha$ : the ARCH effect; $\beta$ : the GARCH effect; $\gamma:$ the leverage effect.

(ii) ***, and $* * *$ indicate that the variable is statistically significant at $10 \%, 5 \%$, and $1 \%$, respectively. 


\section{Robustness}

The above outcomes reveal that remittances can mitigate the instability of GDP, while FDI may accentuate it. To ascertain the robustness of these results, we performed several estimates of the link between economic growth volatility and financial flows (REM and FDI) by incorporating control variables that may deeply explain the volatile GDP behavior (lagged GDP, squared lagged GDP, credits, openness) and by employing naïve models (standard deviation, moving average deviation and absolute average deviation) and different GARCH extensions (linear vs. nonlinear and symmetrical vs. asymmetrical). Details about these estimates are reported in Appendix 3 and Appendix 4. Comparing these findings with those of the optimal specification, we notice that the effect of financial flows on the volatility of Moroccan economic growth is fairly robust.

The main results reported in Table 6 indicate that remittances have a negative and significant impact on Moroccan GDP volatility, whereas the influence of FDI appears positive and statistically significant. These findings do not change substantially among the different GARCH models used (Appendix 5), when accounting for the control variables (Appendix 6), when carrying out further GARCH specifications (Appendix 5 and Appendix 6) or when applying naïve models (Appendix 7), thus reinforcing the robustness of our results.

We can therefore confirm that remittances play a stabilizing role on Moroccan economic growth, while FDI acts as destabilizing element. These outcomes may be beneficial for policymakers, advisers and practitioners in appropriately achieving their decisions-making.

\section{Economic Implications}

One of the main roles of policymakers is to ensure a credible budget and to allow reliable budget forecasts to be made in good time. However, these can only be achieved if actual conditions do not change or change marginally. In the present paper, we have shown that FDI seems highly volatile compared to remittances. This evidence which is valid whatever the criterion used may be highly important for a country like Morocco characterized by an unstable growth. This instability is mainly due to weather 
conditions, which are long periods of drought followed by heavy rainfall. Despite the efforts regularly pursued by Moroccan governments, the relationship between climate and economic growth remains substantial and becomes increasingly tenuous. It must be stressed, in that context, that the agricultural sector is still a potential component of national wealth. Even agricultural value added amounts less than $20 \%$ of the national wealth for several years ago, almost the half of Moroccan population lives in rural areas today ( $48 \%$ of total population). Similarly, the share of food industry in total manufacturing industries is not negligible (24\%, MEDISCO ${ }^{7} 2008$ ). To this, we must add the possible induced effects of drought on the country, for example, a demoralizing effect, time losses and then productivity losses for business leaders of food industry, etc. In other words, agriculture weight in national wealth is much more than it appears (14 16\% of GDP). This shows the interest of the obtained results, including the fact that migrants' remittances mitigate the volatility of growth, while FDI accentuates it. In light of the sizable volatility of the Moroccan growth, our findings indicating that remittances play a smoothing role on excessive GDP variability seem fundamental. This may limit wide variation of consumption, and maintain balanced and fixed income of households. From a macroeconomic viewpoint, migrants' remittances can lessen the effects of internal exogenous shocks, e.g., drought, and external ones which are crisis and sudden short-run disturbances, etc. We can detect from this outcome that remittances are essentially due to altruistic reasons unlike FDI which is expected to depend profoundly on profits of foreign investors. Considering the current economic crisis, we notice that remittances have decreased by $7.95 \%$ while FDI have fallen by $12.7 \%$ over the period 2007 2008. Thereafter and particularly during the period 2008 2009, remittances have dropped by $2.38 \%$ and then stabilized, while FDI have declined considerably by about $20.11 \%$ in 2009 and $37.05 \%$ in 2010 .

Furthermore, the bulk of remittances goes into consumption increases the domestic demand and leads to the stabilization of demand in the case of exogenous shock. Moreover, it must be mentioned that much of remittances goes to the real estate industry and this has been for several years. This phenomenon related to real estate speculation doesn't win Morocco recently and the impact of remittances on the sector would be very beneficial for the country which has a cheap labor and available inputs (cement, sand, etc.) in sufficient quantity. Despite the positive impact of remittances, it remains limited, because of the weak absorption capacity and assets regarding investment opportunity. If

MEDISCO or the MEDiterranean food and agro Industry applications of Solar COoling technologies is a co-funded project aiming at developing and enhancing solar thermally driven cooling concepts for the food and agro industries among the Mediterranean countries. 
migrants have strongly invested in building, it is primarily because it is the only field that market is able to offer. Then, it is the only sector where the risks are seemingly limited. In addition, it is an investment that, for many migrants, is a culmination after many years of effort and sacrifice in their host countries. Given the above elements, the authorities should establish a clear and credible policy to redirect remittances to more productive sectors. Certainly the FDI flows are important and their recent evolution appears encouraging, despite the onset of the global economic crisis and the aftermath of Arab Spring, their spillovers are almost non-existent because of their concentration in sectors with low capital intensity.

These considerations should encourage the government to implement proactive and favourable policies geared towards productive investment. In other words, the authorities should focus on stimulating long-term FDI with high value-added sectors like automobiles, aerospace, electronics. At the same time, they should give more incentives to Moroccans living abroad to invest in their origin country, instead of simply focusing on helping their families through consumption. This involves the establishment of effective, accountable and transparent institutions at all levels. The challenge lies in understanding how to appropriately achieve all these measures.

\section{Conclusion}

The present research aims at addressing the degree of variability of the main financial flows on the one hand and to see whether these flows play potentially role on Moroccan economic growth volatility on the other hand.

The results highlight the paramount importance of accounting for asymmetry and nonlinearity when analyzing the volatility processes of GDP, remittances, and FDI. We also show that the remittances behave better than FDI with respect the duration, the intensity, and volatility clustering. We suggest thus that remittances are more stable than FDI.

Another primary goal of this study was to go beyond this conclusion and evaluate whether the remittances stabilize Moroccan growth. Our findings tend to confirm the evidence that remittances mitigate the volatility of growth, while FDI accentuate it. We attribute the first finding to altruistic foundations, the counter-cyclical behavior 
of remittances (Makhlouf 2013) and the concentration of Moroccans in Europe which is $80 \%$ of the total number of migrants and almost $50 \%$ in France in particular. This concentration allows remittances to be relatively stable (Mouhoud 2010, Bouoiyour 2013). The second finding may be due to the fact that FDI flows depend greatly on the decisions of foreign investors who search a profitable economic environment for their investments. This can explain the remarkable sensitivity of these flows to economic conditions. In this sense, FDI are pro-cyclical.

To ensure the robustness of our findings, we have performed several estimates of the relationship between economic growth volatility and financial flows by incorporating control variables as main drivers of GDP instability including domestic credits and openness, and by carrying out different naïve models and further GARCH extensions. The obtained outcomes do not seem sensitive to the inclusion of additional explanatory variables and the use of different specifications.

Based on the obtained results of this study, we can argue that Morocco has won a first round. Thanks to the efforts of policymakers, this country has succeeded to attract remittances of its nationals living abroad, while developing a safe and stable financial system. It remains a second round to be won by the drainage of considerable funds into productive and innovative investment projects. This is still far from being met today, despite the proactive measures implemented by the authorities responsible for migration affairs. This is true for FDI as the incentives are required from public authorities towards the sectors producing value added.

Received 22 July 2014, Revised 7 October 2015, Accepted 6 January 2016

\section{References}

Aggarwal, R, Demirgüç-Kunt, A and Pería, MSM. "Do Workers' Remittances Promote Financial Development?” World Bank Policy Research Working Paper 3957 (2006).

Alfaro, L., Charlton, A., "Growth and the quality of foreign direct investment: is all FDI equal?" CEP Discussion Papers dp0830 (2007), Centre for Economic Performance, LSE. 
Amuedo-Dorantes, $\mathrm{C}$ and Pozo, S. "Workers' remittances and the real exchange rate: A paradox of gifts." World Development, 32 (2004), 1407-1417.

Arab, C. "La migracion circular femina marroqui en Huelva." Impacto y cambio. Revista de ciencias sociale, 5 (2011), 165-175.

Bauwens, L., and Storti, G. "A component GARCH model with time varying weights." Studies in nonlinear dynamics and econometrics, Manuscript 1512 (2008).

Ben Seddik, S.M. "Développement rural et transition démographique. Le cas du Maroc." PhD dissertation in Economics defended at the University of Pau (2011).

Bollerslev, T. "Generalized autoregressive conditional heteroscedasticity." Journal of Econometrics, 31 (1986), 307-327.

Bollerslev T., Engle, R.F. and Nelson, D.B. "ARCH models in Handbook of Econometrics IV.” (1993).

Bollerslev, T. "Glossary to ARCH (GARCH).” CREATES Research Papers 49 (2008), School of Economics and Management, University of Aarhus.

Borensztein, E. De Gregorio, J. and Lee, J-W. "How Does Foreign Direct Investment Affect Economic Growth?” Journal of International Economics, 45 (1998), 115-135.

Boufraioua, L., "Le role des pères sur les trajectoires de vie des enfants à Sidi Ifni (Maroc). In: veillassent de la population dans les pays du Sud. Famille, conditions de vie, solidarités publiques et privées... État des lieux et perspectives." Actes du colloque international de Meknès, Maroc (17-19 mars 2011).

Bouhga-Hagbe, J. “Altruism and worker's remittances: Evidence from selected countries in the Middle East and Central Asia." IMF Working paper WP/06/130 (2006).

Bouoiyour, J. "Diaspora et dévelopement: Quelles intercations dans le cas marocain?" MPRA Paper 37216 (2008).

Bouoiyour, J. "Les transferts des fonds des migrants marocains: Leviers de croissance et du développement." MPRA Paper 50537 (2013).

Bouoiyour, J. and Selmi, R. "Commodity price uncertainty and manufactured exports in Morocco and Tunisia: Some insights from a novel GARCH model." Economics Bulletin, 34 (2014), 220-233. 
Bouoiyour, J. and Miftah, A. "The Effects of Remittances on Poverty and Inequality: Evidence from Rural Southern Morocco." Working paper, CATT, University of Pau (2014).

Bouoiyour J., Miftah A., Mouhoud E.M. "Education, male gender preference and migrants' remittances: Interactions in rural Morocco." Economic Modelling (2015), http://dx.doi.org/10.1016/j.econmod.2015.10.026.

Bouoiyour, J., Miftah, A. "Migration, remittances and educational levels of household members left behind: Evidence from rural Morocco." European Journal of Comparative Economics, 12 (2015), 21-40.

Bugamelli M. and Paterno F. "Output growth volatility and remittances." Economic working papers 673 (2008), Bank of Italy, Economic Research Department.

Caballero, J.R. "Macroeconomic Volatility in Latin America: A View and Three Case Studies." NBER Working Papers 7782 (2011), National Bureau of Economic Research.

Chami, R., Fullenkamp, C. and Jahjah, S. "Are immigrant remittance flows a source of capital for development?” IMF Working Paper WP/03/189 (2003).

Chami, R., Fullenkamp, C. and Jahjah, S., "Are immigrant remittance flows a source of capital for development. IMF Staff Papers, 52 (2005), 55-81.

Choe, J.I. "Do foreign direct investment and gross domestic investment promote economic growth?" Review of Development Economics, 7 (2003), 44-57.

Courbage Y. "Transition féconde en contexte peu propice: Le Maroc de 1962 à 1994." Congés Régionale Arabe de population (1996).

Ding Z., Granger, C.W. and Engle, R.F. "A long memory property of stock market returns and a new model." Journal of Empirical Finance, 1 (1993), 83-106.

Easterly, W., R. Islam, and Stiglitz, J. E. "Shaken and stirred: Explaining growth volatility." Annual World Bank Conference on Developmen Economics (2000), 191-211.

Ebeke, C. and Combes, J-L. "Do remittances dampen the effects of natural disasters in developing countries?" Applied Economics (2012).

Engle, R.F. "Autoregressive Conditional Heteroskedasticity with Estimates of the Variance of U.K. Inflation.” Econometrica 50 (1982). 
Engle, R.F. and T. Bollerslev. "Modelling the persistence of conditional variances," Econometric Reviews, 5 (1986), 1-50.

Engle, R. F., Lilien, D. M. and Robins, R. P. "Estimating Time Varying Risk Premia in the Term Structure: The Arch-M Model.” Econometrica 55 (1987), 391-407.

El-Sakka, M. I. T., and McNabb, R. "The Macroeconomic Determinants of Emigrant Remittances." World Development 27(1999), 1493-1502.

Glytsos N. P. "Dynamic Effects of Migrant Remittances on Growth: An Econometrics Model with an Application to Mediterranean Countries." Discussion Paper 74 (2002), Labour and Demography.

Görg, H. and Strobl, E. "Spillovers from Foreign Firms through Worker Mobility: An Empirical Investigation.” Discussion Papers of DIW Berlin 463 (2004), German Institute for Economic Research.

Guillaumont, P. and Le Goff, M. "Aid and remittances: their stabilizing impact compared." (2010).

Hermes, N., and Lensink, R. "Foreign direct Investment, Financial Development and Economic Growth.” The Journal of Development Studies, 40 (2003), 142-163.

Higgins, M.L. and Bera, A.K. "A Class of nonlinear Arch models." International Economic Review 33 (1993), 137-158.

Jackman M., Roland C. and Winston M. "Economic volatility and remittances: evidence from SIDS.” Journal of Economic Studies, 36 (2010), 135-146.

Keller, W. and Yeaple, S.R. "Multinational Enterprises, International Trade and Productivity Growth: Firm-Level Evidence from the US." CEPR Discussion Papers 3805 (2003).

Koksal, B. "A comparison of conditional volatility estimators for the ISE national index returns." Journal of Economic and Social Research 11 (2009), 1-28.

Lucas, R.E.B. and Stark, O. "Motivations to Remit: Evidence from Botswana." Journal of Political Eocnomy, 93 (1985), 901-918.

Makhlouf, F. "Transferts de fonds vers le Maroc, enjeux, comportement et impacts." PhD dissertation in Economics presented and defended at the University of Pau (2013). 
Mansuri, G. "Migration, school attainment, and child labor: evidence from rural Pakistan." Policy Research Working Paper Series 3945 (2006), The World Bank.

McCormick, B. and Wahba, J. "Overseas Work Experience, Savings and Entrepreneurship Amongst Return Migrants to LDCs." Journal of African economies 12 (2003), 500-532.

MEDISCO. "Mediterranean food and agro Industry applications of Solar Cooling technologies." Project 032559 (2008).

Mesnard, A. "Temporary migration and capital market imperfections." Oxford Economic papers 56 (2004).

Mouhoud, E. M. "Migrations, transferts et inégalités," Apports de travaux économiques, 61 (2010), 973-979.

Neagu, I.C. and Schiff M. "Remittance stability, cyclicality and stabilizing impact in developing countries.” Policy Research Working Paper Series 5077 (2009).

Nelson, D.B. "Conditional heteroskedasticity in asset returns: a new approach." Econometrica 59 (1991).

Rao, B. and Hassan, G. "Are the Direct and Indirect Growth Effects of Remittances Significant?" MPRA Paper 1864 (2009).

Ratha, D. "Workers.Remittances: An Important and Stable Source of External Development Finance." in Global Development Finance: Striving for Stability in Development Finance. Washington: World Bank(2003), 157-175.

Tong, H. "Nonlinear time series analysis since 1990: Some personal reflections." University of Hong Kong and London school economics (1990).

Valero-Gil, J. "Remittances and the household's expenditures on health." MPRA Paper 9572 (2008).

Zakoian, J.M. "Threshold Heteroskedastic Models." Journal of Economic Dynamics and Control, 18 (1994), 931-955.

Woodruff, C.M. and Zenteno, R. "Remittances and Microenterprises in Mexico." SSRN Electronic Journal (2001), DOI: 10.2139/ssrn.282019. 


\section{Appendix 1: GARCH extensions used in this study}

\begin{tabular}{|c|c|c|c|c|}
\hline Extensions & Linear & Nonlinear & Symmetrical & Asymmetrical \\
\hline $\begin{array}{l}\text { GARCH-M (GARCH in mean, Bollerslev et al. 1993) } \\
r_{t}=\mu_{t}+\varepsilon_{t}+\lambda \sigma_{t}^{2}\end{array}$ & $\mathrm{x}$ & & $\mathrm{x}$ & \\
\hline $\begin{array}{l}\text { C-GARCH (Component GARCH, Ding et al. 1993) } \\
\left(\sigma_{t}^{2}-\sigma^{2}\right)=\alpha\left(\varepsilon_{t_{-}}^{2}-\sigma^{2}\right)+\beta\left(\sigma_{t_{-}}^{2}-\sigma^{2}\right)\end{array}$ & $\mathrm{x}$ & & $\mathrm{x}$ & \\
\hline $\begin{array}{l}\text { I-GARCH (Integrated GARCH, Bollerslev et al. 1993) } \\
\sigma_{t}^{2}=\omega+\varepsilon_{t-1}^{2}+\sum_{i=1}^{q} \alpha_{i}\left(\varepsilon_{t-i}^{2}-\varepsilon_{t-1}^{2}\right)+\sum_{i=1}^{p} \beta_{j}\left(\sigma_{t-j}^{2}-\varepsilon_{t-1}^{2}\right)\end{array}$ & $x$ & & $\mathrm{x}$ & \\
\hline $\begin{array}{l}\text { T-GARCH (Threshold GARCH, Zakoian, 1994) } \\
\sigma_{t}^{2}=\omega+\sum_{i=1}^{q}\left(\alpha_{i}\left|\varepsilon_{t-i}\right|+\gamma_{i}\left|\varepsilon_{t_{-} i}^{+}\right|\right)+\sum_{i=1}^{p} \beta_{j} \sigma_{t-j}\end{array}$ & & $\mathrm{x}$ & & $x$ \\
\hline $\begin{array}{l}\text { E-GARCH (Exponential GARCH, Nelson, 1991) } \\
\log \left(\sigma_{t}^{2}\right)=\omega+\sum_{i=1}^{q}\left(\alpha_{i} z_{t-i}+\gamma_{i}\left(\left|z_{t-i}\right|-\sqrt{2 / \pi}\right)\right)+\sum_{i=1}^{p} \beta_{j} \log \left(\sigma_{t-j}^{2}\right)\end{array}$ & & & & $x$ \\
\hline $\begin{array}{l}\text { P-GARCH (Power GARCH, Higgins and Bera, 1992) } \\
\sigma_{t}^{\varphi}=\omega+\sum_{i=1}^{q} \alpha_{i} \varepsilon_{t-i}^{\varphi}+\sum_{i=1}^{p} \beta_{j} \sigma_{t-j}^{\varphi}\end{array}$ & $\mathrm{X}$ & & $\mathrm{x}$ & \\
\hline $\begin{array}{l}\text { A-PGARCH (Asymmetric power GARCH, } \\
\text { Ding et al., 1993) } \\
\sigma_{t}^{\varphi}=\omega+\sum_{i=1}^{q} \alpha_{i}\left(\left|\varepsilon_{t-i}\right|+\gamma_{i} \varepsilon_{t-i}\right)^{\varphi}+\sum_{i=1}^{p} \beta_{j} \sigma_{t-j}^{\varphi}\end{array}$ & & & & $\mathrm{x}$ \\
\hline $\begin{array}{l}\text { CMT-GARCH (Component with Multiple Thresholds } \\
\text { GARCH, Bouoiyour and Selmi, 2014) } \\
\sigma_{t}^{2}=\omega+\alpha \varepsilon_{t-1}^{2}+\beta\left(\omega+\left(\alpha+\gamma I_{\left(\varepsilon_{t-2 \succ 0}\right)}\right) \varepsilon_{t-2}^{2}+\beta \sigma_{t-2}^{2}\right)\end{array}$ & & $\mathrm{X}$ & & $\mathrm{X}$ \\
\hline
\end{tabular}

(Note) $\sigma_{t}^{2}$ : the conditional variance, $\alpha_{0}$ : the reaction of shock, $\alpha_{1}$ : the ARCH term, $\beta_{1}$ : the GARCH term, $\varepsilon$ : the error term; $I_{\mathrm{t}}$ : denotes the information set available at time $\mathrm{t} ; z_{t}$ : the standardized value of error term where $z_{t}=\varepsilon_{t-1} / \sigma_{t-1} ; \mu$ : the innovation, $\gamma$ : the leverage effect; $\varphi$ : the power parameter. 


\section{Appendix 2: Volatilities of GDP and financial flows}

\begin{tabular}{|c|c|c|c|c|c|c|}
\hline \multicolumn{7}{|c|}{ GDP } \\
\hline Models & AIC & BIC & HQ & RMSE & MAE & BP \\
\hline GARCH & -3.8419 & -3.6220 & -3.7652 & 0.0326 & 0.0247 & 0.0000 \\
\hline GARCH-M & -3.7812 & -3.5173 & -3.6891 & 0.9562 & 0.3410 & 0.0127 \\
\hline I-GARCH & -4.2065 & -4.0746 & -4.1605 & 0.0316 & 0.0241 & 0.0003 \\
\hline C-GARCH & -3.7495 & -3.4416 & -3.6421 & 0.0326 & 0.0247 & 0.0010 \\
\hline CMT-GARCH & -3.7677 & -3.4158 & -3.6448 & 0.0316 & 0.0239 & 0.0011 \\
\hline T-GARCH & -3.9209 & -3.6130 & -3.8134 & 0.0317 & 0.0238 & 0.0069 \\
\hline E-GARCH & -3.8498 & -3.5859 & -3.7577 & 0.0238 & 0.0246 & 0.0004 \\
\hline P-GARCH & -3.8585 & -3.6386 & -3.7818 & 0.0237 & 0.0248 & 0.0002 \\
\hline AP-GARCH & -3.8184 & -3.5544 & -3.7262 & 0.0323 & 0.0244 & 0.0032 \\
\hline \multicolumn{7}{|c|}{ REMITTANCES } \\
\hline GARCH & 2.5109 & 2.7286 & 2.5877 & 0.8606 & 0.6477 & 0.0024 \\
\hline GARCH-M & 2.5045 & 2.7657 & 2.5966 & 0.8979 & 0.6621 & 0.0779 \\
\hline I-GARCH & 2.4973 & 2.7282 & 2.5887 & 0.8604 & 0.6272 & 0.0021 \\
\hline C-GARCH & 2.6189 & 2.9237 & 2.7264 & 0.8607 & 0.6471 & 0.0026 \\
\hline CMT-GARCH & 2.3269 & 2.5302 & 2.3610 & 0.8547 & 0.6269 & 0.0004 \\
\hline T-GARCH & 2.3398 & 2.6010 & 2.4319 & 0.8728 & 0.6350 & 0.0176 \\
\hline E-GARCH & 2.4671 & 2.7322 & 2.4964 & 0.8753 & 0.6412 & 0.0029 \\
\hline P-GARCH & 2.4934 & 2.7111 & 2.5701 & 0.8625 & 0.6281 & 0.0019 \\
\hline AP-GARCH & 2.8045 & 3.1529 & 2.9273 & 0.8718 & 0.6321 & 0.0042 \\
\hline \multicolumn{7}{|c|}{$F D I$} \\
\hline GARCH & -0.3567 & -0.3190 & -0.4600 & 0.1759 & 0.1381 & 0.0141 \\
\hline GARCH-M & -0.5539 & -0.2927 & -0.4618 & 0.1753 & 0.1476 & 0.0000 \\
\hline I-GARCH & -0.6892 & -0.5586 & -0.6432 & 0.1820 & 0.1424 & 0.0016 \\
\hline C-GARCH & -0.5432 & -0.2384 & -0.4357 & 0.1750 & 0.1389 & 0.0074 \\
\hline CMT-GARCH & -0.2639 & 0.0843 & -0.1411 & 0.1731 & 0.1444 & 0.0000 \\
\hline T-GARCH & -0.7320 & -0.4255 & -0.6228 & 0.1717 & 0.1381 & 0.0048 \\
\hline E-GARCH & -0.4604 & -0.1992 & -0.3683 & 0.1746 & 0.1395 & 0.0055 \\
\hline P-GARCH & -0.5915 & -0.3738 & -0.5148 & 0.1743 & 0.1454 & 0.0040 \\
\hline AP-GARCH & -0.5470 & -0.2857 & -0.4549 & 0.1734 & 0.1426 & 0.0029 \\
\hline
\end{tabular}

(Note) AIC: Akaike Information Criterion, BIC: Bayesian Information Criterion, HQ: Hannan-Quinn, RMSE: Root Mean Square Error, MAE: Mean Absolute Error, BP: Bias Proportion. 


\section{Appendix 3: Relationship between GDP volatility and financial flows}

\begin{tabular}{|l|c|c|c|c|c|c|}
\hline \multicolumn{1}{|c|}{ Models } & AIC & BIC & HQ & RMSE & MAE & BP \\
\hline GARCH & -5.097127 & -5.757346 & -5.382416 & 0.0740116 & 0.055702 & 0.002016 \\
\hline GARCH-M & -5.10918 & -5.780313 & -5.426894 & 0.7353801 & 0.055616 & 0.063099 \\
\hline I-GARCH & -5.069519 & -5.756502 & -5.384496 & 0.0705528 & 0.048294 & 0.001596 \\
\hline C-GARCH & -5.316367 & -6.169007 & -5.670912 & 0.0740202 & 0.038826 & 0.002236 \\
\hline CMT-GARCH & -4.723607 & -5.338722 & -4.91088 & 0.0735042 & 0.050152 & 0.000344 \\
\hline T-GARCH & -4.749794 & -5.495913 & -5.058352 & 0.0750608 & 0.051435 & 0.015136 \\
\hline E-GARCH & -5.008213 & -5.764942 & -5.192512 & 0.0715732 & 0.055143 & 0.002494 \\
\hline P-GARCH & -5.061602 & -5.720421 & -5.345808 & 0.0739162 & 0.054016 & 0.001634 \\
\hline AP-GARCH & -5.693135 & -5.852619 & -5.887841 & 0.0709748 & 0.47606 & 0.001538 \\
\hline
\end{tabular}

(Note) AIC: Akaike Information Criterion, BIC: Bayesian Information Criterion, HQ: Hannan-Quinn, RMSE: Root Mean Square Error, MAE: Mean Absolute Error, BP: Bias Proportion.

\section{Appendix 4: Relationship between GDP volatility, financial flows and control variables}

\begin{tabular}{|l|c|c|c|c|c|c|}
\hline Models & AIC & BIC & HQ & RMSE & MAE & BP \\
\hline GARCH & -3.304034 & -3.31492 & -3.362768 & 0.151274 & 0.118766 & 0.011844 \\
\hline GARCH-M & -3.096802 & -3.954532 & -3.995549 & 0.143570 & 0.123984 & 0.057984 \\
\hline I-GARCH & -3.461949 & -3.537442 & -3.56198 & 0.149786 & 0.109648 & 0.01216 \\
\hline C-GARCH & -3.241442 & -3.168208 & -3.132206 & 0.1512875 & 0.087507 & 0.06364 \\
\hline CMT-GARCH & -3.240222 & -3.869272 & -3.134528 & 0.158866 & 0.128296 & 0.054066 \\
\hline T-GARCH & -3.371974 & -3.926531 & -3.279524 & 0.147662 & 0.111861 & 0.04128 \\
\hline E-GARCH & -3.118338 & -3.183874 & -3.189322 & 0.141426 & 0.11997 & 0.01023 \\
\hline P-GARCH & -3.306734 & -3.129196 & -3.264071 & 0.1493751 & 0.125044 & 0.034524 \\
\hline AP-GARCH & -3.483824 & -3.956784 & -3.999436 & 0.149124 & 0.122636 & 0.054056 \\
\hline
\end{tabular}

(Note) AIC: Akaike Information Criterion, BIC: Bayesian Information Criterion, HQ: Hannan-Quinn, RMSE: Root Mean Square Error, MAE: Mean Absolute Error, BP: Bias Proportion. 


\section{Appendix 5: Link between economic growth volatility and financial flows}

\begin{tabular}{|c|c|c|c|c|c|c|c|c|c|}
\hline \multicolumn{10}{|c|}{ Dependent variable: $\left(r_{t}=\log \left(G D P_{t}\right)-\log \left(G D P_{t-1}\right)\right.$} \\
\hline & GARCH & \begin{tabular}{|c} 
GARCH- \\
$\mathrm{M}$
\end{tabular} & $\begin{array}{c}\mathrm{I}- \\
\text { GARCH } \\
\end{array}$ & $\begin{array}{c}\mathrm{C}- \\
\text { GARCH }\end{array}$ & $\begin{array}{c}\text { CMT- } \\
\text { GARCH }\end{array}$ & $\begin{array}{c}\text { T- } \\
\text { GARCH }\end{array}$ & \begin{tabular}{|c|} 
E- \\
GARCH \\
\end{tabular} & $\begin{array}{c}\text { P- } \\
\text { GARCH }\end{array}$ & $\begin{array}{c}\text { AP- } \\
\text { GARCH }\end{array}$ \\
\hline \multicolumn{10}{|c|}{ Mean equation } \\
\hline$C$ & $\begin{array}{l}0.03723 \\
(1.4319)\end{array}$ & $\begin{array}{c}0.0262 \\
(1.5706)\end{array}$ & $\begin{array}{c}0.1644 * * * \\
(6.5190)\end{array}$ & $\begin{array}{c}0.0458 \\
(0.7634)\end{array}$ & $\begin{array}{c}0.0922 \\
(1.3742)\end{array}$ & $\begin{array}{c}0.0687 \\
(1.3469)\end{array}$ & $\begin{array}{c}0.0644^{*} \\
(1.7110)\end{array}$ & $\begin{array}{c}0.0580 \\
(1.1953)\end{array}$ & $\begin{array}{c}0.0729 \\
(1.0676)\end{array}$ \\
\hline $\begin{array}{c}R E M / \\
G D P\end{array}$ & \begin{tabular}{|c}
$-0.0286^{*}$ \\
$(-1.617)$
\end{tabular} & $\begin{array}{l}-0.0196 \\
(-0.523)\end{array}$ & $\begin{array}{l}-2.6 \\
0\end{array}$ & $\begin{array}{l}-0.0552 \\
(-0.948)\end{array}$ & $\begin{array}{l}-0.0433 * \\
(-1.6902)\end{array}$ & $\begin{array}{r}-0.0578^{*} \\
(-1.968)\end{array}$ & $\begin{array}{l}-0.0691 \\
(-0.316)\end{array}$ & $\begin{array}{c}-0.0494 * \\
(-1.830)\end{array}$ & $\begin{array}{l}-0.0352^{*} \\
(-1.7215)\end{array}$ \\
\hline $\begin{array}{l}F D I / \\
G D P\end{array}$ & $\begin{array}{l}0.0082 * \\
(1.9256)\end{array}$ & $\begin{array}{l}0.0096 * \\
(1.7233)\end{array}$ & $\begin{array}{c}0.0439 * * * \\
(4.0031)\end{array}$ & $\begin{array}{c}0.0040 \\
(0.1750)\end{array}$ & $\begin{array}{l}0.0234^{*} \\
(1.8925)\end{array}$ & $\begin{array}{c}0.0117 \\
(1.5234)\end{array}$ & $\begin{array}{l}0.0084 * \\
(1.6230)\end{array}$ & $\begin{array}{c}0.0083 \\
(0.0678)\end{array}$ & $\begin{array}{c}0.00676^{*} \\
(1.6784)\end{array}$ \\
\hline \multicolumn{10}{|c|}{ Variance equation } \\
\hline$\omega$ & $\begin{array}{l}0.0005^{*} \\
(1.9375)\end{array}$ & $\begin{array}{l}0.0006^{*} \\
(1.8150)\end{array}$ & - & $\begin{array}{l}0.0005^{*} \\
(1.8657)\end{array}$ & $\begin{array}{c}0.0006 \\
(1.2017)\end{array}$ & $\begin{array}{l}0.0003 * \\
(1.6880)\end{array}$ & $\begin{array}{c}-0.0855^{*} \\
(-1.8523)\end{array}$ & $\begin{array}{l}0.0232^{*} \\
(1.8133)\end{array}$ & $\begin{array}{c}3.00 \mathrm{E}-05 \\
(0.9984)\end{array}$ \\
\hline$\alpha$ & $\begin{array}{c}0.3971 \\
(1.2725)\end{array}$ & \begin{tabular}{c|c}
0.6196 \\
$(1.3821)$
\end{tabular} & $\begin{array}{l}-0.1552 * * * \\
(-18.3667)\end{array}$ & $\begin{array}{c}0.6212 \\
(0.4415)\end{array}$ & $\begin{array}{c}0.5827 \\
(0.3224)\end{array}$ & $\begin{array}{c}0.7787 \\
(0.8575)\end{array}$ & $\begin{array}{l}0.8486^{*} \\
(1.6735)\end{array}$ & $\begin{array}{l}0.5132^{*} \\
(1.6653)\end{array}$ & $\begin{array}{c}-0.0683 \\
(-0.9227)\end{array}$ \\
\hline$\beta$ & $\begin{array}{c}-0.4641 \\
(-0.7960)\end{array}$ & $\begin{array}{l}-0.4629 * \\
(-1.6825)\end{array}$ & $\begin{array}{l}1.1552 * * * \\
(13.6674)\end{array}$ & $\begin{array}{c}0.3175 \\
(0.2879)\end{array}$ & $\begin{array}{l}0.1428^{*} \\
(1.9926)\end{array}$ & $\begin{array}{l}-0.0462 * \\
(-1.7066)\end{array}$ & $\begin{array}{c}-0.1917 \\
(-1.3757)\end{array}$ & $\begin{array}{c}-0.4566 \\
(-0.7681)\end{array}$ & $\begin{array}{c}0.9925 \\
(0.3588)\end{array}$ \\
\hline$\gamma$ & - & - & - & - & $\begin{array}{l}0.4982 * \\
(1.6096)\end{array}$ & $\begin{array}{c}-0.1275 \\
(-0.5612)\end{array}$ & $\begin{array}{l}-0.1256^{* *} \\
(-2.1384)\end{array}$ & - & $\begin{array}{c}1.0580^{* * *} \\
(4.2153)\end{array}$ \\
\hline
\end{tabular}

(Notes) (i) $\omega$ : the reaction of conditional variance; $\alpha$ : the ARCH effect; $\beta$ : the GARCH effect; $\gamma$ : the leverage effect.

(ii) $* * *$, and $* * *$ indicate that the variable is statistically significant at $10 \%, 5 \%$, and $1 \%$, respectively. 


\section{Appendix 6: Link between economic growth volatility, financial flows and other control variables}

\begin{tabular}{|c|c|c|c|c|c|c|c|c|c|}
\hline \multicolumn{10}{|c|}{ Dependent variable: $\left(r_{t}=\log \left(G D P_{t}\right)-\log \left(G D P_{t-1}\right)\right.$} \\
\hline & GARCH & \begin{tabular}{|c|} 
GARCH- \\
$\mathrm{M}$
\end{tabular} & $\begin{array}{c}\mathrm{I}- \\
\text { GARCH } \\
\end{array}$ & \begin{tabular}{|c|}
$\mathrm{C}-$ \\
GARCH \\
\end{tabular} & $\begin{array}{c}\text { CMT- } \\
\text { GARCH }\end{array}$ & $\begin{array}{c}\mathrm{T}- \\
\text { GARCH }\end{array}$ & $\begin{array}{c}\text { E- } \\
\text { GARCH } \\
\end{array}$ & \begin{tabular}{|c|} 
P- \\
GARCH \\
\end{tabular} & \begin{tabular}{|c} 
AP- \\
GARCH \\
\end{tabular} \\
\hline \multicolumn{10}{|c|}{ Mean equation } \\
\hline$C$ & $\begin{array}{l}92.36^{* * *} \\
(14.3140)\end{array}$ & $\begin{array}{l}95.783^{* * *} \\
(23.0247)\end{array}$ & $\begin{array}{l}92.38^{* *} \\
(2.3867)\end{array}$ & $\begin{array}{c}92.3 * * * \\
(27.90)\end{array}$ & $\begin{array}{l}92.372^{* * * *} \\
(18.6354)\end{array}$ & $\begin{array}{l}92.2820^{* * *} \\
(14.9530)\end{array}$ & $\begin{array}{c}92.4390^{* * *} \\
(8.1778)\end{array}$ & $\begin{array}{l}92.39^{* * *} \\
(8.9007)\end{array}$ & $\begin{array}{l}92.33^{* * *} \\
(6.8479)\end{array}$ \\
\hline $\begin{array}{c}R E M / \\
G D P\end{array}$ & $\begin{array}{c}-0.0212 \\
(-0.2040)\end{array}$ & $\begin{array}{l}-0.0415^{*} \\
(-1.6853)\end{array}$ & $\begin{array}{l}-0.027^{*} \\
(-1.876)\end{array}$ & \begin{tabular}{|c|c}
-0.0286 \\
$(-0.782)$
\end{tabular} & $\begin{array}{l}-0.0293^{*} \\
(-1.8840)\end{array}$ & $\begin{array}{l}-0.0348 * * \\
(-2.6641)\end{array}$ & $\begin{array}{l}-0.0519 * \\
(-1.7785)\end{array}$ & \begin{tabular}{|c|c}
$-0.054^{* *}$ \\
$(-2.355)$
\end{tabular} & $\begin{array}{c}-0.0486 * \\
(-1.759)\end{array}$ \\
\hline $\begin{array}{l}F D I / \\
G D P\end{array}$ & $\begin{array}{c}0.0457^{*} \\
(1.9461)\end{array}$ & $\begin{array}{l}0.02215 \\
(0.1850)\end{array}$ & $\begin{array}{c}0.0224 \\
(0.1850)\end{array}$ & $\begin{array}{l}0.021 * * \\
(2.4125)\end{array}$ & $\begin{array}{l}0.0252 * \\
(1.7459)\end{array}$ & $\begin{array}{c}0.0412 \\
(1.3814)\end{array}$ & $\begin{array}{c}0.0397 \\
(0.4093)\end{array}$ & $\begin{array}{c}0.0421 \\
(0.3941)\end{array}$ & $\begin{array}{l}0.0464 * \\
(1.6184)\end{array}$ \\
\hline$G D P(t-1)$ & $\begin{array}{l}-15.2 * * * \\
(-8.8687)\end{array}$ & $\begin{array}{l}-15.8097 \\
(-8.2200)\end{array}$ & $\begin{array}{l}-15.2 * * \\
(-2.361)\end{array}$ & $\begin{array}{c}-15.24^{*} \\
(-2.110)\end{array}$ & $\begin{array}{l}-15.24 * * * \\
(-10.284)\end{array}$ & $\begin{array}{l}-15.244 * * * \\
(-16.8401)\end{array}$ & $\begin{array}{c}-15.239 * * * \\
(-8.2262)\end{array}$ & $\begin{array}{l}-15.2 * * * \\
(-8.226)\end{array}$ & $\begin{array}{c}-15.2 * * * \\
(-6.980)\end{array}$ \\
\hline$G D P(t-1)^{2}$ & $\begin{array}{l}0.6688 * * \\
(2.2814)\end{array}$ & $\begin{array}{l}0.6923 * * * \\
(10.9402)\end{array}$ & $\begin{array}{l}0.668^{* *} \\
(2.3833)\end{array}$ & $\begin{array}{l}0.66^{* * *} \\
(6.5482)\end{array}$ & $\begin{array}{l}0.6632 * * * \\
(17.5896)\end{array}$ & $\begin{array}{c}0.6692 * * * \\
(3.3843)\end{array}$ & $\begin{array}{c}0.6678^{* * *} \\
(8.2262)\end{array}$ & $\begin{array}{l}0.667^{* * *} \\
(9.1056)\end{array}$ & $\begin{array}{l}0.668^{* * *} \\
(5.9180)\end{array}$ \\
\hline Credits & $\begin{array}{l}-0.42 * * * \\
(-4.7278)\end{array}$ & $\begin{array}{l}-0.426^{* * *} \\
(-4.5842)\end{array}$ & $\begin{array}{l}-0.42 * * \\
(-2.417)\end{array}$ & $\begin{array}{c}-0.4 * * * \\
(3.4853)\end{array}$ & $\begin{array}{l}-0.408^{* * * *} \\
(-6.5070)\end{array}$ & $\begin{array}{l}-0.4280 * * * \\
(-5.2057)\end{array}$ & $\begin{array}{c}-0.4224 * * * \\
(-7.3138)\end{array}$ & \begin{tabular}{|c|c}
$-0.41 * * *$ \\
$(-6.671)$
\end{tabular} & $\begin{array}{l}-0.42 * * * \\
(-6.690)\end{array}$ \\
\hline Openness & \begin{tabular}{c|c|}
0.02038 & \\
$(0.3560$ &
\end{tabular} & $\begin{array}{c}0.0516 \\
(1.3594)\end{array}$ & $\begin{array}{c}0.0442 \\
(0.6005)\end{array}$ & $\begin{array}{l}0.0407^{*} \\
(1.6820)\end{array}$ & $\begin{array}{l}0.0416^{*} \\
(1.7544)\end{array}$ & $\begin{array}{l}0.0035^{*} \\
(1.6176)\end{array}$ & $\begin{array}{c}0.0553 \\
(1.1308)\end{array}$ & $\begin{array}{l}0.0531 * \\
(1.6211)\end{array}$ & $\begin{array}{l}0.0412 * \\
(1.6544)\end{array}$ \\
\hline \multicolumn{10}{|c|}{ Variance equation } \\
\hline$\omega$ & $\begin{array}{c}1.39 \mathrm{E}-05 \\
(0.4329)\end{array}$ & $\begin{array}{l}\text { 7.49E-05 } \\
(1.1820)\end{array}$ & - & \begin{tabular}{|l|l}
$0.0003 *$ \\
$(2.1694)$
\end{tabular} & $\begin{array}{c}0.0001^{* *} \\
(2.7791)\end{array}$ & $\begin{array}{c}1.94 \mathrm{E}-05^{*} \\
(2.0266)\end{array}$ & $\begin{array}{c}-7.1489 \\
(-0.8120)\end{array}$ & $\begin{array}{l}0.0270^{* *} \\
(2.1167)\end{array}$ & $\begin{array}{c}0.0236 \\
(1.3189)\end{array}$ \\
\hline$\alpha$ & $\begin{array}{c}-0.1612 * * \\
(-2.1855)\end{array}$ & $\begin{array}{c}-0.1423 \\
(-1.2518)\end{array}$ & $\begin{array}{c}0.0561 \\
(0.5176)\end{array}$ & \begin{tabular}{|c|c}
0.5000 \\
$(0.2916)$
\end{tabular} & $\begin{array}{l}0.7191^{*} \\
(1.1460)\end{array}$ & $\begin{array}{c}0.0014 \\
(0.0316)\end{array}$ & $\begin{array}{c}-0.6269 \\
(-0.9457)\end{array}$ & $\begin{array}{l}-0.349^{* * * *} \\
(-3.6632)\end{array}$ & $\begin{array}{c}-0.0821 \\
(-0.1967)\end{array}$ \\
\hline$\beta$ & $\begin{array}{l}1.1086^{* * * *} \\
(10.8037)\end{array}$ & $\begin{array}{c}0.9192^{* * *} \\
(6.7612)\end{array}$ & $\begin{array}{c}0.9438 * * * \\
(8.7020)\end{array}$ & \begin{tabular}{|l|l}
$0.0399^{*}$ \\
$(1.8482)$
\end{tabular} & $\begin{array}{c}0.2114 \\
(0.3239)\end{array}$ & $\begin{array}{c}0.3708^{* *} \\
(2.6033)\end{array}$ & $\begin{array}{c}-0.1223 \\
(-0.2786)\end{array}$ & $\begin{array}{c}-0.1018 \\
(-0.1832)\end{array}$ & \begin{tabular}{c}
-0.0221 \\
$(-0.0243)$ \\
\hdashline
\end{tabular} \\
\hline$\gamma$ & - & - & - & - & $\begin{array}{c}-0.0224 \\
(-0.0088)\end{array}$ & $\begin{array}{c}0.3867 * * \\
(2.7453)\end{array}$ & $\begin{array}{c}0.0281 \\
(0.0241)\end{array}$ & - & $\begin{array}{c}0.1419 * \\
(1.8734)\end{array}$ \\
\hline
\end{tabular}

(Notes) (i) $\omega$ : the reaction of conditional variance; $\alpha$ : the $\mathrm{ARCH}$ effect; $\beta$ : the GARCH effect; $\gamma$ : the leverage effect.

(ii) ***, and $* * *$ indicate that the variable is statistically significant at $10 \%, 5 \%$, and $1 \%$, respectively. 
Appendix 7: The link between economic growth volatility, financial flows and other control variables in naïve models

\begin{tabular}{|c|c|c|c|c|c|c|}
\hline \multicolumn{7}{|c|}{ Dependent variable: $G D P$} \\
\hline & \multicolumn{2}{|c|}{$S D$} & \multicolumn{2}{|c|}{$M A D$} & \multicolumn{2}{|c|}{$A A D$} \\
\hline & (1) & (2) & (3) & (4) & (5) & (6) \\
\hline $\mathrm{C}$ & $\begin{array}{c}1.8722 * * \\
(2.5643)\end{array}$ & $\begin{array}{c}3.0114 * * * \\
(4.6915)\end{array}$ & $\begin{array}{c}1.9115^{* * * *} \\
(3.4782)\end{array}$ & $\begin{array}{l}2.7539 * \\
(1.8654)\end{array}$ & $\begin{array}{c}2.0142 * * \\
(2.5601)\end{array}$ & $\begin{array}{c}3.1579 * * * \\
(6.0012)\end{array}$ \\
\hline$R E M / G D P$ & $\begin{array}{c}-0.0067 \\
(-1.1038)\end{array}$ & $\begin{array}{c}-0.0034 \\
(-1.2155)\end{array}$ & $\begin{array}{l}0.0054 * \\
(1.7213)\end{array}$ & $\begin{array}{l}0.0037 * \\
(1.6822)\end{array}$ & $\begin{array}{l}-0.0032 * \\
(-1.8928)\end{array}$ & $\begin{array}{l}-0.0031^{*} \\
(-1.6954)\end{array}$ \\
\hline$F D I / G D P$ & $\begin{array}{l}0.0135^{*} \\
(1.6912)\end{array}$ & $\begin{array}{l}0.0125 * * \\
(2.8810)\end{array}$ & $\begin{array}{c}0.02218^{* *} \\
(2.4569)\end{array}$ & $\begin{array}{l}0.0154^{*} \\
(1.6017)\end{array}$ & $\begin{array}{c}0.0195 \\
(1.5436)\end{array}$ & $\begin{array}{l}-0.0137^{*} \\
(-1.6994)\end{array}$ \\
\hline$G D P(t-1)$ & - & $\begin{array}{c}-6.7892 * * * \\
(-4.5543)\end{array}$ & - & $\begin{array}{c}-8.0215^{* * *} \\
(-6.7119)\end{array}$ & - & $\begin{array}{c}-6.0732 * * * \\
(-5.6954)\end{array}$ \\
\hline$G D P(t-1)^{2}$ & - & $\begin{array}{l}8.0416^{*} \\
(1.9455)\end{array}$ & - & $\begin{array}{c}8.7914 * * * \\
(3.2100)\end{array}$ & - & $\begin{array}{c}7.1892 * * * \\
(6.0008)\end{array}$ \\
\hline Credits & - & $\begin{array}{c}-0.4356^{* *} \\
(-2.7110)\end{array}$ & - & $\begin{array}{c}-0.3985 * * * \\
(-3.1254)\end{array}$ & - & $\begin{array}{c}-0.4013 * * \\
(-2.8152)\end{array}$ \\
\hline Openness & - & $\begin{array}{c}0.0329 \\
(0.8865)\end{array}$ & - & $\begin{array}{l}0.0350^{*} \\
(1.6628)\end{array}$ & - & $\begin{array}{c}0.0367 \\
(1.2058)\end{array}$ \\
\hline
\end{tabular}

(Notes) (i) $S D$ : the standard deviation; $M A D$ : the moving average deviation $\left(V O L=\left[(1 / m) \sum_{i=1}^{m}\left(e_{t+i-1}-e_{t+i-2}\right)^{2}\right]^{1 / 2}\right)$; $A A D$ : the absolute average deviation $\left(V O L=\left[(1 / n) \sum_{i=1}^{n}\left(e_{i}-\overline{e_{i}}\right)\right]^{1 / 2}\right)$.

(ii) *,**, and $* * *$ indicate that the variable is statistically significant at $10 \%, 5 \%$, and $1 \%$, respectively. 